\title{
Hommage à Fernand Turcotte, ancien rédacteur chez la RCSP
}

\section{Tribute to Fernand Turcotte, former editor with the CJPH}

\author{
Jean Rochon ${ }^{1}$
}

Published online: 11 August 2020

(C) The Canadian Public Health Association 2020

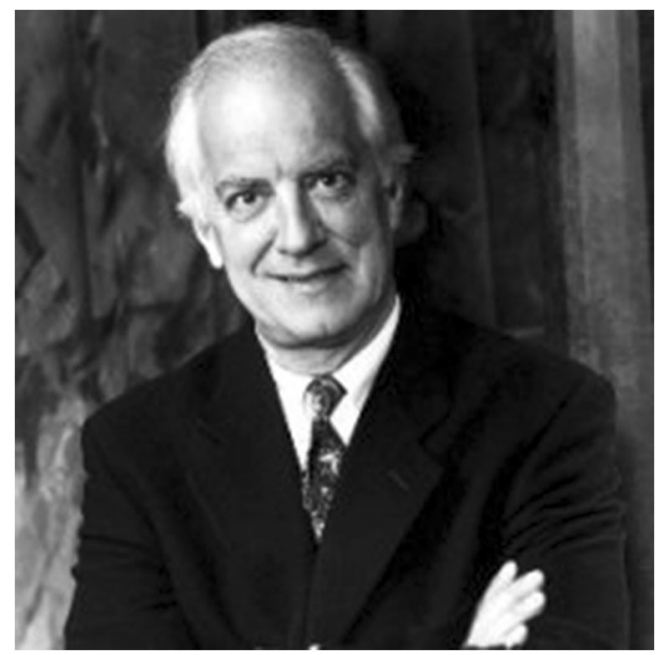

Fernand Turcotte

Préface de la Rédactrice-en-chef : Notre collègue Fernand Turcotte, qui fut Associate Editor/Rédacteur-en-chef adjoint de la Revue canadienne de santé publique de 1982 à 2001 est décédé à Québec, de la COVID-19 le 16 mai 2020. Pour lui rendre hommage, nous avons ouvert nos pages à son ami et complice de longue date, le $D^{r}$ Jean Rochon. Rappelons que $D^{r}$ Rochon fut le Directeur inaugural du Département de médecine sociale et préventive et Doyen de la Faculté de médecine de l'Université Laval. Il fut aussi membre du Gouvernement du Québec où il occupa le poste de Ministre de la santé et des services sociaux de 1994 à 1998.

Fernand Turcotte était un collègue depuis cinquante ans et un ami. Il était de la toute première équipe à la création du département de médecine sociale et préventive de la faculté de médecine de l'Université Laval en 1970. Il a été directeur du département de 1979 à 1985.

\section{Jean Rochon}

Montréal, Québec, Canada
Il était un enseignant très apprécié par les étudiants. Ses collègues pouvaient compter sur sa disponibilité, son empressement à explorer de nouvelles avenues et sa capacité de travailler en équipe. En santé au travail, il a assumé un leadership pour le développement d'un certificat et a innové en expérimentant l'enseignement en ligne et en offrant des sessions de formation dans différentes régions du Québec.

De plus, il a maintenu une pratique professionnelle en santé publique et en santé au travail et a assumé la direction du département de santé communautaire du Centre hospitalier de l'Université Laval de 1975 à 1979. Il a développé une expertise clinique spécialisée en travaillant comme consultant dans différentes mines au Québec.

Fernand Turcotte était un battant qui s'est investi dans plusieurs causes pour la santé de la population. Sa contribution a grandement influencé la reconnaissance des problèmes de santé reliés à l'amiante et à la consommation du tabac. Par ailleurs, il a lutté contre des abus ou des dérives des services de santé comme le dépistage inapproprié, le surdiagnostic et le surtraitement. Dans tous ces secteurs, son activité était toujours intense et s'inscrivait dans la durée jusqu'à la réalisation de changements significatifs concrétisés par de nouvelles législations ou de nouveaux protocoles de pratiques professionnelles. Pour les personnes et pour les groupes avec qui il travaillait, Fernand témoignait une grande générosité et une fidélité à travers toutes les difficultés.

Dans tous ses domaines d'activités, il a approfondi et partagé la connaissance des données probantes par ses publications et par la traduction de livres, discuté des enjeux pour la santé en participant à des colloques, des conférences et des groupes de travail, enrichi le débat public avec les groupes socioéconomiques et communautaires et conseillé les gouvernements. Il a participé activement aux organisations nationales et internationales devenant un expert reconnu. En 1998, l'Association canadienne de santé publique lui a décerné sa plus haute distinction, le Prix R. D. Defries en reconnaissance de sa contribution exceptionnelle au domaine de la santé publique. 
Il était un personnage haut en couleur qui avait son francparler. Il avait le don de présenter et d'expliquer de façon très pédagogique, convaincante et parfois même imagée. Je n'oublierai jamais l'anecdote, au début de l'existence du département de médecine sociale et préventive, lors d'une rencontre avec une équipe du MSSS que nous souhaitions convaincre de la nécessité de réaliser une étude et de la capacité de notre équipe d'en assumer la responsabilité. Au cœur de la discussion, j'entends Fernand déclarer à brûle-pourpoint qu'on pouvait nous faire confiance parce que nous étions une bande d'ignorants... Nous avons tous été interloqués et je dis adieu à l'opportunité d'obtenir le financement de l'étude... Mais après quelques secondes, pour que l'effet se produise, Fernand complète sa phrase en affirmant : mais nous n'ignorons pas tous les mêmes choses! Le financement fut accordé...! On pourrait colliger un catalogue des déclarations et des réparties de Fernand.

Son départ inopiné au plus fort de la pandémie, est à l'image du personnage. Autant pouvait-il être flamboyant, autant savait-il s'intégrer et se fondre dans une équipe. Il soutenait l'effort et le succès collectif. Je crois que cette citation de Douglas MacArthur illustre très bien la situation : « Les vieux soldats ne meurent pas; ils ne font que s'estomper. » (Old soldiers never die; they just fade away.)

Jean Rochon, LL.L, MD, DrPH

\section{Editorial}

Preface from the Editor-in-Chief: Our colleague Fernand Turcotte, who was Associate Editor/Rédacteur-en-chef adjoint of the Canadian Journal of Public Health from 1982 to 2001, passed away from COVID-19 on May 16, 2020. To pay tribute to him, we have opened our pages to his close, longtime friend Dr. Jean Rochon. You will remember Dr. Rochon as the first Director of the Department of Social and Preventive Medicine and Dean of the Faculty of Medicine at Laval University. He was also a member of the Québec Government where he was Minister of Health and Social Services from 1994 to 1998.

Fernand Turcotte was a colleague for fifty years and a friend. In 1970, he was part of the very first team in the creation of the Department of Social and Preventive Medicine in Laval University's Faculty of Medicine. He was Head of the Department from 1979 to 1985.

As a teacher, he was very much appreciated by his students. His colleagues could count on his availability, his willingness to explore new avenues and his capacity to work as part of a team. In occupational health, he took a leadership position in developing a certificate and innovated in experimenting with online learning and in offering training in various regions of Québec.

In addition, he maintained a professional practice in public health and in workplace health and assumed the leadership of the Department of Community Health at Laval University's Centre Hospitalier from 1975 to 1979 . He developed a specialized clinical expertise while working as a consultant for various mines in Québec.

Fernand Turcotte was a fighter who was committed to many population health causes. His contribution greatly influenced recognition of health problems linked to asbestos and to tobacco consumption. In addition, he fought against abuses or excesses in healthcare services such as inappropriate testing, over-diagnosis and overtreatment. In all of these sectors, his involvement was always passionate and he stayed involved until the realization of significant changes, by new legislation or new protocols for professional practice, was assured. For the individuals or the groups with whom he worked, Fernand demonstrated great generosity and loyalty throughout all difficulties.

In all his fields of endeavour, he deepened and shared knowledge of evidence-informed data through his publications and by the translation of books; furthered discussion of health issues by participating in seminars, conferences and workgroups; enriched public debate with socio-economic and community groups; and advised governments. He participated actively in national and international organizations, becoming a recognized expert. In 1998, the Canadian Public Health Association awarded him their highest distinction, the R. D. Defries Award, in recognition of his exceptional contribution to the field of public health.

He was a colourful, outspoken personality. He had the gift of presenting and explaining in a very pedagogical, convincing and sometimes even imaginative way. I will never forget an anecdote, in the early days of the Department of Social and Preventive Medicine, during a meeting with a team from the MSSS. We wanted to convince them how important it was to carry out a study and of our team's capacity to assume responsibility for it. In the midst of the discussion, I hear Fernand state - pointblank - that they could have confidence in us because we were a bunch of know-nothings... We were all taken aback and I waved goodbye to the chance of getting funding for the study... But, after a few seconds to let the words sink in, Fernand finished his statement saying: but we do not all "not know" the same things! The funding was granted! One could compile an entire catalogue of Fernand's statements and repartees.

His unexpected departure at the height of the pandemic is reflective of his personality. At times, Fernand could be flamboyant, yet he also knew how to integrate and blend into a team. He supported collective effort and success. I believe that this quote from Douglas MacArthur illustrates the situation very well- "Old soldiers never die; they just fade away."

Jean Rochon, LL.L, MD, DrPH

Publisher's note Springer Nature remains neutral with regard to jurisdictional claims in published maps and institutional affiliations. 